Research Article

\title{
Obstetric Risk Factors and Anal Incontinence among Women with Previous History of Vaginal Delivery
}

\author{
Faktor Risiko Obstetri dan Kejadian Inkontinensia Ani pada \\ Ibu Riwayat Persalinan Pervaginam
}

\author{
Azizah Nurdin, Trika Irianta, Mardiah Tahir, Maisuri T. Chalid \\ Department of Obstetrics and Gynecology \\ Faculty of Medicine Universitas Hasanuddin/ \\ Dr. Wahidin Sudirohusodo Hospital \\ Makassar
}

\begin{abstract}
Objective: To investigate the obstetric risk factors of the anal incontinence in mothers with previous history of vaginal delivery.

Methods: The was a case-control study conducted in the Obstetrics and Gynecology Department of Dr.Wahidin Sudirohusodo Hospital, Faculty of Medicine, Universitas Hasanuddin, Makassar, during the period of February 2015 through January 2016. The research instruments were used to evaluate obstetric risk factors and the anal incontinence was the self-administered questionnaire and Fecal Incontinence Severity Index. The data were analyzed statistically using the Chi-square test with the significant value of $p<0.05$.

Results: A total of 300 subjects were recruited in this study. The research results indicated that the parity of $\geq 3$, the assisted vaginal delivery history (vacuum extraction), and the prolong second stage of labor had a significant correlation with the anal incontinence with $\mathrm{p}$ value $=0.026, \mathrm{OR}(95 \% \mathrm{CI})=1.8(1.07-3.03), \mathrm{p}=0.018$ with OR $(95 \% \mathrm{CI})=3.65(1.2-10.7)$ and $\mathrm{p}=0.006$ with $\mathrm{OR}(95 \% \mathrm{CI})$ $=2.9(1.2-6.7)$.The history of episiotomy and the delivery of the baby $\geq 4000$ gram had no correlation with the anal incontinence.

Conclusion: Parity, vacuum delivery and prolong second stage of labor have an association with anal incontinence among women who has history of vaginal delivery.

[Indones J Obstet Gynecol 2018; 6-1: 55-59]
\end{abstract}

Keywords: anal incontinence, obstetric risk factors, vaginal delivery

\begin{abstract}
Abstrak
Tujuan: Untuk mengetahui beberapa faktor risiko obstetrik terhadap kejadian inkontinensia ani pada ibu riwayat persalinan pervaginam.

Metode: Penelitian ini dilaksanakan di RS Wahidin Sudirohusodo dan jejaringnya di bagian obstetrik dan ginekologi yang dimulai pada tanggal 1 Februari 2015 sampai 31 Januari 2016. Metode yang digunakan adalah desain case-control dengan sampel berjumlah 300 orang. Instrumen yang digunakan untuk menilai faktor risiko obstetrik dan inkontinensia ani adalah self-adminnistered questionnaire dan fecal incontinence severity index. Data diolah dengan uji Chisquare dan tingkat signifikansi $p<0,05$.

Hasil: Hasil penelitian ini menunjukkan bahwa paritas $\geq 3$, riwayat persalinan vakum dan riwayat kala II lama berhubungan secara bermakna dengan kejadian inkontinensia ani di mana nilai $p$ masing-masing 0,026 dengan OR $(95 \% C I)=1,8(1,07-3,03)$, $p=0,018$ dengan OR $(95 \% C I)=3,65(1,2-10,7)$ dan $p=0,006$ dengan OR $(95 \% C I)=2,91(1,2-6,7)$. Riwayat episiotomi dan persalinan bayi $\geq 4000$ gram tidak memiliki hubungan bermakna dengan inkontinensia ani.

Kesimpulan: Paritas, persalinan vakum dan kala II lama berhubungan dengan kejadian inkontinensia ani pada perempuan riwayat persalinan pervaginam.
\end{abstract}

[Maj Obstet Ginekol Indones 2018; 6-1: 55-59]

Kata kunci: faktor risiko obstetri, inkontinensia ani, persalinan pervaginam

\section{INTRODUCTION}

Anal incontinence is a medical condition that affects quality of life. The prevalence of anal incontinence in the world varies from $0.4 \%$ to $20 \% .^{1,2}$ Research in the United States got a prevalence for women and men as much as $2.6 \%$ in men aged 20-29 years and increased to $15.3 \%$ in men aged 70 years and over ${ }^{3}$, and the French as much as $9.5 \%$ at age $50-61$ years. ${ }^{1}$ In Indonesia, the prevalence of anal incontinence has not well documented. One of community study among aged over 60 years, the prevalence is $22.4 \%{ }^{4}$
Anal incontinence is defined as in voluntary loss of feces either liquid or solid. ${ }^{5}$ Epidemiology consensus of anal incontinence define it as all incontinence of flatus, feces, liquid or solid that affect the quality of life of individuals.

The normal bowel movement is a combined process of somatoviseral response involving colo-recto-anal functions. The continence is a physiological complex function that requires coordination of brain, central nervous system, autonomic nervous system, the enteric; gastrointestinal tract and other biomechanical 
capabilities including anal sphincter. ${ }^{6}$ The ability to evacuate stool is influenced by several factors including the sphincter mechanism, detention reservoir, volume and consistency of stool, gut motility, the structural integrity of the pelvic wall, rectal sensation, colonic transit, and the sensation of anorectal reflex Incontinence occurs if one or more of these mechanalsmsis disrupted and other can not compensate. ${ }^{7}$

Numerous factors are associated with the occurrence of anal incontinence, such as age, obesity, obstetric trauma, chronic illnesses such as diabetes, rectal prolapse, colitis, rectal surgery, surgery for urinary incontinence and others. Independent risk factors that plays an important role is anal sphincter injury during childbirth. ${ }^{8}$

Anal incontinence is a symptom that initially assessed through a subjective assessment. One example of self-completion questionnaires, standardized, valid and reliable questionnaire is from the University of Auckland. This questionnaire was developed and validated in New Zealand, has obtained permission, using the Bristol Stool Form Scale, fecal incontinence severity index, and the index level of quality of life in anal incontinence. ${ }^{9}$

The obstetric risk factors of anal incontinence have been studied abroad, but in Indonesia, it still limited. Currently the research in community more than 60 years has been conducted in Bali. However study subjected to reproductive age has not been established. Therefore, the authors aims to identify the association of obstetric risk factors and anal incontinence in women with history of vaginal delivery. Identification of the risk factor will be highly beneficial for increasing women's quality of life.

\section{METHODS}

The was a case-control study. The research variables consisted of independent variable (obstetric risk factors include: parity, episiotomy, vacuum delivery, birth weight, prolonged second stage) and dependent variable (anal incontinence).

The research was conducted in Dr. Wahidin Sudirohusodo Teaching Hospital and its network, Obstetrics and Gynecology Department, Faculty of Medicine, Universitas Hasanuddin, Makassar.
The sample was all women aged 20-55 years who had a history of vaginal delivery without any comorbid diseases, willing to participate and signed the informed consent. A self administered questionnaire filled out by the respondents and the anal incontinence were scored. The collected data were analyzed. Data analysis were conducted using SPSS with $2 \times 2$ table to get an odds ratio, where the significance is determined by the value of $\mathrm{p}<0.05$.

\section{RESULTS}

A total of 300 subjects were involved in this study. Majority of the respondents were aged less than 35 years, 171 (57\%) and 129 (43\%) were aged greater than or equal to 35 years. The majority of the samples were highly educated as much as 221 $(73.7 \%)$ while less educated were $79(26.3 \%)$. In terms of occupation, most of the samples did not work, 195 women (65\%) and the counterpart were 105 (35\%). The majority of respondent has normal body mass index as much as 207 (69\%), overweight $70(23.3 \%)$, underweight $15(5 \%)$ and obesity $8(2.7 \%)$. In terms of obstetric history, the majority of the sample had children less than 3 as much as $185(61.7 \%)$. The samples have experienced an episiotomy was 104 (34.7), the assisted delivery with vacuum experienced by 32 people $(10.7 \%)$ and had delivered a baby more or equal to $4000 \mathrm{~g}$ as much as 12 (4\%). Women with a history of prolonged second stage were 45 people.

Table 1. Respondents' Characteristics

\begin{tabular}{lcc}
\hline \hline Characteristics & Frequensi (n) & \% \\
\hline Age (years) & 171 & 57 \\
$<35$ & 129 & 43 \\
$\geq 35$ & & \\
Education & 79 & 26.3 \\
Low (<9 years) & 221 & 73.7 \\
High ( $\geq 9$ years ) & & \\
Occupation & 195 & 65 \\
Not Working & 105 & 35 \\
Working & & \\
Body Mass Index & 15 & 5 \\
Underweight & 207 & 69 \\
Normal weight & 70 & 23.3 \\
Over weight & 8 & 2.7 \\
Obesity &
\end{tabular}




\begin{tabular}{lcc} 
Parity & & \\
$<3$ & 185 & 61.7 \\
$\geq 3$ & 115 & 38.3 \\
History of Episiotomy & & \\
No & 196 & 65.3 \\
Yes & 104 & 34.7 \\
History of Vacuum Extraction & & \\
No & 268 & 89.3 \\
Yes & 32 & 10.7 \\
History of Large Baby & & \\
No & 288 & 96 \\
Yes & 12 & 4 \\
History of prolonged second & & \\
stage of labor & & \\
No & 255 & 85 \\
Yes & 45 & 15 \\
Total & 300 & 100 \\
\hline \hline
\end{tabular}

Bivariate analysis examines the relationship between parity and anal incontinence in women with a history of vaginal delivery. It shows that there is a significant relationship between parity and anal incontinence, $\mathrm{p}$-value is 0.026 ( $\mathrm{p}$ value $<0.05$ with OR $(95 \% \mathrm{CI})=1.806$ (1.07- 3:03)). Women with parity more than or equal to three are more likely to having anal incontinence 1.8 times compared with their counterparts (Appendix, Table 1).

The result shows that there is no significant associaton between episiotomy as well as history of deliver large baby and anal incontinence in women with a history of vaginal delivery. However there is a significant association between a history of delivery with vacuum as well as prolong second stage of labor with the incidence of anal incontinence with $\mathrm{p}$ value $0.018(\mathrm{OR}(95 \% \mathrm{CI})=$ 3.65 (1.24 to 10.74$)$ ) and 0.006 (OR $(95 \% \mathrm{CI})=$ 2.91 (1.24-6.78)), respectively. Women who have a history of vacuum and prolong of second stage of labor is 3.65 and 2.91 times more likely to suffer from anal incontinence compared with their counter parts, respectively. (Appendix, Table 2).

Table 2. The Association Obstetric Risk Factor and Anal Incontinence among Women with History of Vaginal Delivery

\begin{tabular}{|c|c|c|c|c|c|c|c|c|}
\hline \multirow[t]{3}{*}{ Obstetrics Risk factor } & \multicolumn{4}{|c|}{ Anal Incontinence } & \multicolumn{2}{|c|}{ Total } & \multirow[t]{3}{*}{ p value } & \multirow[t]{3}{*}{ OR (95 CI) } \\
\hline & \multicolumn{2}{|c|}{ Yes } & \multicolumn{2}{|c|}{ No } & \multirow[b]{2}{*}{$\mathbf{n}$} & \multirow[b]{2}{*}{$\%$} & & \\
\hline & $\mathbf{n}$ & $\%$ & $\mathbf{n}$ & $\%$ & & & & \\
\hline \multicolumn{9}{|l|}{ Parity } \\
\hline$>=3$ & 87 & 75.7 & 28 & 24.3 & 185 & 100 & $0.026^{*}$ & $1.806(1.07-3.03)$ \\
\hline$<3$ & 117 & & 68 & & 115 & 100 & & \\
\hline \multicolumn{9}{|l|}{ History of Episiotomy } \\
\hline Yes & 74 & 71.2 & 30 & 28.8 & 104 & 100 & 0.236 & \\
\hline No & 130 & 66.3 & 66 & 33.7 & 273 & 100 & & \\
\hline \multicolumn{9}{|c|}{ History of Vacuum Extraction } \\
\hline Yes & 28 & 87.5 & 4 & 12.5 & 32 & 100 & $0.018^{*}$ & $3.65(1.24-10.74)$ \\
\hline No & 176 & 65.7 & 92 & 34.3 & 268 & 100 & & \\
\hline \multicolumn{9}{|c|}{ History of baby $>4000 \mathrm{gr}$} \\
\hline Yes & 10 & 83.3 & 2 & 16.7 & 12 & 100 & 0.202 & \\
\hline No & 194 & 67.4 & 94 & 32.6 & 288 & 100 & & \\
\hline \multicolumn{9}{|c|}{ Prolonged second stage of labor } \\
\hline Yes & 38 & 84.4 & 7 & 15.6 & 45 & 100 & $0.006^{*}$ & $2.91(1.24-6.78)$ \\
\hline No & 166 & 65.1 & 89 & 34.9 & 255 & 100 & & \\
\hline Total & 204 & 68 & 96 & 32 & 300 & 100 & & \\
\hline
\end{tabular}

*Fischer Exact Test 


\section{DISCUSSION}

This study found that women who has anal incontinence is more than $50 \%$. This percentage is quite higher related to definition of anal incontinence we used. It includes of flatal, liquid and stool incontinence.

The study found that parity had a significant relationship with the incidence of anal incontinence in women with a history of vaginal delivery. Contrary to our results, a study done by Fritel (2007), in 2640 women in France showed that parity does not have a significant relationship with the incidence of anal incontinence. However, most surveys found parity as risk factors for anal incontinence. It is said that the first vaginal delivery gives the greatest risk of new onset incontinence anal. ${ }^{10}$

In this study, there was no significant relationship between the incidences of episiotomy with anal incontinence. In line with this study, the research conducted by Fritel (2007), in France in 2640 women shows that there is no significant relationship between the incidences of episiotomy with anal incontinence.

In this study it was found that delivery by vacuum has a significant relationship with the incidence of anal incontinence. Delivery by vacuum was found to be a risk factor for sphincter laceration and anal incontinence. Manometric examination shows that anal squeeze pressure significantly decreased after spontaneous labor and asissted delivery. ${ }^{7}$ Labor manometry provide as an objective evaluation function of the anal sphincter, which reflects the effect of a combination of structural and functional components (especially the internal and external anal sphincter). One of the consistent findings from multiple studies is that anal squeeze pressure was significantly decreased after spontaneous vaginal delivery and instrumental. The majority of studies indicate a problem with anal squeeze pressures as a result of vaginal delivery, regardless of continence status or sphincter integrity. ${ }^{11}$

In the case of anal resting tone, some prospective studies shows a significant decrease in postpartum resting pressures compared with antepartum in people suffering structural damage and underwent instrumental delivery. ${ }^{7}$

The internal anal sphincter is a circular smooth muscle that is responsible for $50-85 \%$ of the resting tone. Several studies indicated that the internal anal sphincter injury occurred up to 35\% of women throughout labor but in this case also usually associated with damage to the external anal sphincter. ${ }^{11}$

Many cases occur where sphincter incontinence morphologically intact but compromised in terms of sensation. Pelvic wall are very susceptible to trauma caused by stretching, especially at the time of delivery. The rectum does not have proprioseptor and only owned by the levator, puborectalis and anal sphincter which supply the sensation of stretching and wrinkling of the rectal wall. These sensations are supplied along the pudendal nerve to the end of S2, S3 and S4. ${ }^{7}$ If there is an injury to the pudendal nerve or its branch, the sensation of the continence will be disrupted. The response of the external anal sphincter to increased intraabdominal pressure, dilated anal and rectal distension is in the form of contraction. In normal conditions, these contractions can last 40-60 seconds to allow time for the rectum to accommodate the feces, but in vaginal delivery or emergency caesarean section where there is trauma or excessive stretching of the birth canal can result in the abnormal contraction of external anal sphincter causing incontinence. ${ }^{7}$

This study found no significant relationship between large baby $(\geq 4,000$ grams) with the incidence of anal incontinence. Other studies have shown a relationship between anal incontinence and fetal weight over 4000 grams. $^{12}$

The result of this study in line with the other that found a statistically significant association between prolonged second stage of labor and anal incontinence. ${ }^{12}$ At the time of delivery, the descent process of the head on the pelvic wall can stretch the pelvic and the pudendal nerve. The nerve consists of sensoric and motoric nerve fibers that are very susceptible to stretching or trauma. Histological study showed that there is a necrosis in the muscular wall of the pelvis and the electromyographic study found reinnervation of pelvic wall on the pudendal nerves. This is due to injury of pelvic wall during labor. ${ }^{7}$

In our study, there are several limitations. Like most other case-control study that using a selfadministered questionnaire, it has recall bias as obstetric history of respondents obtained solely from the patient recall and not based on medical records. In addition, complaints about 
incontinence ranging from flatus, liquid to solid are assessed subjectively from the patients and confirmation test can not be done. Even so, several other studies have also used the same questionnaire as a baseline study to assess the risk factors. As a strength of ours, only limited study has been conducted in Indonesia. Previous research conducted in Bali incommunities over 60 years. This study examines the age of 20 to 55 years in order to specifically identify the obstetric risk factors in earlier symptomps.

\section{CONCLUSIONS AND RECOMMENDATIONS}

The researchers concluded that women has three or more children, having history of vacuum and prolonged second stage of labor were more likely to have anal incontinence than women in their counterpart. Researchers suggested that the socialization of obstetrics risk factor related to anal incontinence needs to be improved in community. Moreover, improving the skills of midwives and health care personnel in order to minimize the birth trauma and prolonged second stage of labor is needed as a process for preventing anal incontinence.

\section{REFFERENCES}

1. Fritel X, Ringa V, Varnoux N, Zins M, Breart. Mode of Delivery and Fecal Incontinence at Midlife: a Study of 2640 Women in the Gazel Cohort. Obstet Gynecol. 2007: 31-8.

2. Trowbridge. Updates on the treatment of the fecal incontinence. Virginia: ACG/VGS/ODSGNA Regional Postgraduate Course. Female Pelvic Medicine and Reconstructive Sur. 2014: 1-20.

3. Whitehead WE, Borroud l, Ye W. Fecal incontinence in U.S. adults: Epidemiology and Risk Factors. Gastroenterol. 2009; 137: 512-7.

4. Suyasa IG. Prevalence of Fecal Incontinence in Community Dwelling Older People in Indonesia. National Conference on Incontinence. Melbourne: Victoria. 2011: 1-15.

5. Rush. Fecal Incontinence. Rush University Medical Centre. 2013: 1-3.

6. Scott. Risk Factors in Fecal Incontinence. In Ratto C \& Doglietto G. Fecal Incontinence Diagnosis and Treatment. Italy: Springer. 2007: 43-4.

7. Bharucha E, Blanon ER. Anatomy and Physiology Continence in Ratto C \& Doglietto G; Fecal Incontinence Diagnosis and Treatment. Italy: Springer. 2007: 3-10.

8. Moore. Fecal incontinence: New Treatment Options. Sinai: Colorectal Cancer Centre Cedars-Sinai Med Center. 2012: 1-18.

9. Macmillan AK, Merrie AE, Marshal RJ, Parry BR. The Prevalence of Fecal Incontinence in Community-Dwelling Adults: A Systematic Review of the Literature. Dis Colon Rectum. 2007; 4: 1341-9.

10. Laine K, Skjeldelstad FE, Sanda B, Horne H, Spydslaug A. Prevalence and Risk Indicators for Anal Incontinence. Hindawi Publishing Corporation. ISRN Obstet Gynecol. 2013: 1-8.

11. Sultan. Perineal and Anal Sphincter Trauma Diagnosis and Clinical Management. London: Springer-Verlag. 2007: 3-45.

12. Hatem M, Pasquier JC, Fraser W, Lepire E. Factors Associated With Postpartum Urinary/Anal Incontinence in Primiparous Women in Quebec. J Obstet Gynaecol Can. 2007; 29(3): 232-9. 